\title{
Oxidative DNA damages by chemical exposures at work
}

\author{
Kyung-Taek Rim \\ Occupational Safety and Health Research Institute, Korea Occupational Safety and Health Agency, Incheon, Republic of Korea \\ Email: rim3249@gmail.com
}

Received 14 August 2012; revised 20 September 2012; accepted 11 October 2012

\begin{abstract}
Oxidative DNA damage is an inevitable consequence of cellular metabolism, with a propensity for increased levels following toxic insult. Of the molecules subject to oxidative modification, DNA has received the greatest attention, with biomarkers of exposure and effect closest to validation. There are many chemicals in workplaces that could cause oxidative DNA damages such as carcinogens. This review concentrated on studies published between the years 2000 and 2012 that used to detect 8-oxodG in humans (workers), laboratory animals and in cell lines. Given the recent toxicological results from oxidative stress, it is important to review these studies to improve the current understanding of the oxidative DNA damages by chemical exposures at work. It also suggests that biomarkers may be responsible for understanding the role of oxidative DNA damage in disease, highlighting the need for further studies.
\end{abstract}

Keywords: Oxidative DNA Damage; Industrial Chemicals; Chemoprevention; Workers; Health

\section{INTRODUCTION}

Chemically, oxidative stress is associated with increased production of oxidizing species or a significant decrease in the effectiveness of antioxidant defenses, such as glutathione. Oxidative DNA damage is an inevitable conesquence of cellular metabolism, with a propensity for increased levels following toxic insult.

The generation of reactive oxygen species (ROS) may be both beneficial to cells, performing a function in interand intracellular signalling, and detrimental, modifying cellular biomolecules, accumulation of which has been associated with numerous diseases. Nevertheless, even based simply upon reports of studies investigating the potential role of 8-OH-dG in disease, the weight of evidence strongly suggests a link between such damage and the pathogenesis of disease. There are many reports describing elevated levels of oxidatively modified DNA lesions, in various biological matrices, in a plethora of diseases. These include cancer, Parkinson's disease, Alzheimer's disease, atherosclerosis, heart failure, myocardial infarction, Schizophrenia, bipolar disorder, fragile X syndrome, sickle cell disease and chronic fatigue syndrome. Oxidative stress is likely to be involved in agerelated development of cancer. The reactive species produced in oxidative stress can cause direct damage to the DNA and are therefore mutagenic, and it may also suppress apoptosis and promote proliferation, invasiveness and metastasis [1].

The presence of metals in biological systems in an uncomplexed form (not in a protein or other protective metal complex) can significantly increase the level of oxidative stress. The major portion of long term effects is inflicted by damage on DNA. Some of the less reactive of these species (such as superoxide) can be converted by oxidoreduction reactions with transition metals or other redox cycling compounds (including quinones) into more aggressive radical species that can cause extensive cellular damage. Disturbances in the normal redox state of cells can cause toxic effects through the production of peroxides and free radicals that damage all components of the cell, including proteins, lipids, and DNA. Further, some reactive oxidative species act as cellular messengers in redox signaling. Thus, oxidative stress can cause disruptions in normal mechanisms of cellular signaling. Metals such as iron, copper, chromium, vanadium and cobalt are capable of redox cycling in which a single electron may be accepted or donated by the metal. Most important reactions are probably Fenton's reaction and the Haber-Weiss reaction, in which hydroxyl radical is produced from reduced iron and hydrogen peroxide. The presence of such metals in biological systems in an uncomplexed form (not in a protein or other protective metal complex) can significantly increase the level of oxidative stress. In humans, hemochromatosis is associated with increased tissue iron levels, Wilson's disease with increased tissue levels of copper and chronic manganism with exposure to manganese ores. The reaction of transition metals with proteins oxidated by reactive oxygen species can yield reactive products that accumulate with time and contribute to aging and disease [2].

Occupational and environmental exposures to metals 
are closely associated with an increased risk of various cancers. Although carcinogenesis caused by metals has been intensively investigated, the exact mechanisms of action are still unclear. Accumulating evidence indicates that ROS generated by metals play important roles in the etiology of degenerative and chronic diseases [3].

Oxidative stress-based biomarkers have proved to be essential in revealing how oxidative stress may be mediating toxicity induced by many known carcinogenic environmental or occupational exposures. For example, Arsenic alters multiple cellular pathways including suppression of cell cycle checkpoint proteins, promotion of and resistance to apoptosis, inhibition of DNA repair, alterations in DNA methylation, and increased oxidative stress, by disturbing the pro/antioxidant balance. Arsenic alters cellular glutathione levels either by utilizing this electron donor for the conversion of pentavalent to trivalent arsenicals or directly binding with it or by oxidizing glutathione via arsenic-induced free radical generation. Arsenic forms oxygen-based radicals $\left(\mathrm{OH}^{*}, \mathrm{O}_{2}^{--}\right)$under physiological conditions by directly binding with critical thiols [4].

Several methods have been developed to detect oxidatively damaged DNA. They include chromatographic techniques, the Comet assay, ${ }^{32} \mathrm{P}$-postlabelling and immunochemical methods that use antibodies to detect oxidized lesions. This lesion is frequently used as a marker of exposure to oxidants, including environmental pollutants, as well as a potential marker of disease progression [5]. Especially, the Comet assay (single-cell gel electrophoresis) is a sensitive and simple method for measuring DNA damage. An early modification of the assay involved the application of specific repair endonucleases to convert lesions to breaks; thus, for example, endonuclease III was used to measure oxidized pyrimidines [6].

From the viewpoint of occupational health, the Industrial carcinogens are mainly classified according to the guideline of International Agency for Research on Cancer (IARC) as Group 1, 2A, 2B, 3 and 4. They are also classified by American Conference of Governmental Industrial Hygienists (ACGIH), Occupational Safety and Health Administration (OSHA), National Toxicology Program (NTP). The occupational carcinogen classified by the Occupational Safety and Health Act in Korea is 1A (known or presumed human carcinogens largely based on human evidence), 1B (known or presumed human carcinogens largely based on animal evidence) and 2 (suspected human carcinogens but not sufficiently convincing) [7]. As shown in the Table 1, there are many chemicals in workplaces that could cause oxidative DNA damages such as carcinogens.

This review concentrated on studies published between the years 2000 and 2012 that used to detect 8oxodG in humans (workers), laboratory animals and in cell lines. There are many occupational issues associated with oxidative DNA damages from chemicals at work. Given the recent toxicological results from oxidative stress to cells, animals and workers, it is important to review these studies to improve the current understanding of the oxidative DNA damages by chemical exposures at work. It will be more helpful to establish the sustainable, safe and healthy working environment against oxidative stress from chemical exposure in workplaces.

\section{RECENT IN VITRO ASSAYS FOR OXIDATIVE DNA DAMAGES WITH INDUSTRIAL CHEMICALS}

Oxidative DNA damages can be monitored in a variety of experimental settings. One of the "classical" approaches is the testing of a variety of potential oxidants/ antioxidants in models with subcellular fractions and/or intact cells. On the basis of the results, the most promising compounds can be selected for more expensive experiments, that is, studies with animals and humans.

Halonitromethanes (HNMs) and trichloronitromethane (TCNM) and bromonitromethane (BNM) are genotoxic, inducing high levels of DNA breaks in the Comet assay, and that this DNA damage repairs well over time. In addition, oxidized bases constitute a high proportion of DNA-induced damage $(50 \%-75 \%)$ [8]. Para-phenylenediamine ( $p$-PD), a suspected carcinogen, is a component of permanent hair dyes. It induced DNA damage was confirmed by the comet and TUNEL assays. $p$-PD induced apoptosis through activated initiator caspase- 8 and -9 , and effector caspase-3/7. It was suggested that $p$-PD induce apoptosis which was mediated with caspase- 8 , caspase- 9 and caspase- $3 / 7$ activation via the involvement of ROS [9]. The 4-Monochlorobiphenyl hydroquinone (PCB3-HQ; 2-(4'-chlorophenyl)-1,4-hydroquinone) induced DNA damage and ROS production only at $37^{\circ} \mathrm{C}$ in HL-60 cells in Jurkat cells; no significant DNA damage and ROS production was observed in HL-60 cells at $37^{\circ} \mathrm{C}$ if myeloperoxidase (MPO) activity was inhibited by MPO inhibitor (succinylacetone, SA). These studies show that the effects of PCB3-HQ are enzyme dependent, i.e. PCB3-HQ is oxidized by MPO in HL-60 cells with the generation of ROS and induction of DNA damage. However, this is not the case with the PCB3-pQ, which may produce DNA damage by the reactivity of the quinone with the DNA or nuclear proteins, or possibly by indirectly increasing intracellular ROS levels by glutathione (GSH) depletion [10]. All the phenolic compounds were able to oxidize DNA bases in human lymphocytes, and also observed that pyrimidine bases were more strongly oxidized in comparison to purine ones. It was found that chlorinated catechols and tetrachlorocatechol $(\mathrm{TeCC})$ in particular, revealed a higher oxidative potential in comparison to chlorophe- 
Table 1. Chemicals in workplaces that could cause oxidative DNA damages.

\begin{tabular}{|c|c|c|}
\hline Factor (chemicals etc.) & Industries or Jobs & Target organ \\
\hline $\begin{array}{l}\text { Physical element, } \\
\text { ionizing radiation }\end{array}$ & $\begin{array}{l}\text { Medical doctor of radiology, radiologist, nucleolar worker, radium } \\
\text { dial painter, underground miner, crewman }\end{array}$ & $\begin{array}{l}\text { Bone, leuk(a)emia, lung, liver, thyroid } \\
\text { gland, etc. }\end{array}$ \\
\hline Sunlight & Outdoor worker & Melanoma, skin \\
\hline Dust, fiber, asbestos & $\begin{array}{l}\text { Mining, milling, insulation, shipbuilding, sheet metal worker, } \\
\text { cement }\end{array}$ & $\begin{array}{l}\text { Lung, mesothelioma (larynx, } \\
\text { gastrointestinal tract) }\end{array}$ \\
\hline Erionite & $\begin{array}{l}\text { Waste treatment, sewage, waste from agricultural industry, } \\
\text { environmental pollution control system, cement condensate, } \\
\text { building materials }\end{array}$ & Mesothelioma \\
\hline Silica, crystalline & Granite, stonecutter, ceramic, glass, casting and metal worker & Lung \\
\hline Talc containing asbestiform fibres & Production of chinaware, paper, paint and varnish, cosmetic & Lung, mesothelioma \\
\hline Wood dust & $\begin{array}{l}\text { Felling, lumbering, pulp, paper, paper board, furniture, cabinet, } \\
\text { carpenter, construction }\end{array}$ & Nasal cavity, paranasal sinus \\
\hline $\begin{array}{l}\text { Metal and metallic compound, } \\
\text { Arsenic and arsenic compounds }\end{array}$ & $\begin{array}{l}\text { Refining of nonferrous metals, arsenic compound, agrichemicals, } \\
\text { arsenic mining }\end{array}$ & Skin, lung \\
\hline Beryllium & $\begin{array}{l}\text { Extraction and processing of beryllium, aerospace, electronic and } \\
\text { nuclear industry, jewelry }\end{array}$ & Lung \\
\hline Cadmium (compound) & $\begin{array}{l}\text { Cadmium refining, production of dry cell, cadmium-cupper alloy, } \\
\text { dye or pigment, plating }\end{array}$ & Lung \\
\hline Chromium (VI) (compound) & $\begin{array}{l}\text { Manufacturing of chromic acid, dye or pigment, plating, chromium } \\
\text { alloy, stainless steel welding, preservation of wood, leather } \\
\text { manufacturing, waste water treatment, ink, perfume, etc. }\end{array}$ & Lung \\
\hline $\begin{array}{l}\text { Nickel (compound), } \\
\text { nickel oxide, nickel sulfide }\end{array}$ & Refining of nickel, welding & Lung, nasal cavity, paranasal sinus \\
\hline $\begin{array}{l}\text { Wood, fossil fuel and its by-product } \\
\text { benzene }\end{array}$ & $\begin{array}{l}\text { Solvent for shoe manufacturing, chemicals, pharmaceuticals, } \\
\text { rubber industry, printing, gas additive }\end{array}$ & Leuk(a)emia \\
\hline $\begin{array}{l}\text { Wood, fossil fuel and its by-product, } \\
\text { coal tar and pitch }\end{array}$ & $\begin{array}{l}\text { Manufacturing of purified chemicals, coal tar products, coke, } \\
\text { aluminum, casting, pavement of a road and construction (roof, slater) }\end{array}$ & Skin (lung, bladder) \\
\hline Mineral & Metalwork, machining, printing, production of cosmetic, medicine & Skin (bladder, lung, nasal cavity) \\
\hline Vinyl chloride monomer & $\begin{array}{l}\text { Manufacturing of polyvinyl chloride, refrigerant(before 1974), } \\
\text { extraction of solvent, (vaporizing)high-pressure gas }\end{array}$ & $\begin{array}{l}\text { Liver hemangiosarcoma (hepatocyte } \\
\text { cancer) }\end{array}$ \\
\hline BCME, CME & $\begin{array}{l}\text { Media for manufacturing of plastic or rubber products, alkylating } \\
\text { chemicals, ion exchange resin }\end{array}$ & Lung \\
\hline $\begin{array}{l}\text { Dyes of aromatic amine, } \\
\text { 4-aminobiphenyl, benzidine, } \\
\text { 2-naphthylamine }\end{array}$ & Manufacturing of dyes and pigment & Bladder \\
\hline Agrichemicals, ethylene oxide & Chemical industry, sterilization, disinfection & Leuk(a)emia \\
\hline 2,3,7,8-TCDD & $\begin{array}{l}\text { Herbicide of chlorophenol or chlorophenoxy, incinerator, PCB } \\
\text { manufacturing, bleachinf of pulp or paper }\end{array}$ & $\begin{array}{l}\text { Lung, sarcoma } \\
\text { (most of the body) }\end{array}$ \\
\hline Aflatoxin & Feed production, cargo shipping, processing of rice or corn & Liver \\
\hline Mustard gas & Laboratory, soldier & Larynx (lung, pharynx) \\
\hline $\begin{array}{l}\text { Strong-inorganic-acid mists } \\
\text { containing sulfuric acid }\end{array}$ & $\begin{array}{l}\text { Processing of preserved thing, steel making, petrochemical industry, } \\
\text { phosphatic fertilizer }\end{array}$ & Larynx (lung) \\
\hline Formaldehyde & Pathologist, technician of medical lab, plastic or textile industry & Leuk(a)emia, nasal cavity, pharynx \\
\hline
\end{tabular}




\begin{tabular}{|c|c|c|}
\hline \multicolumn{3}{|l|}{ Continued } \\
\hline Aluminium production & Volatile pitch, aromatic amine & Lung, bladder \\
\hline Auramine production & 2-naphthyl amine, auramine, other chemicals, pigment & Bladder \\
\hline $\begin{array}{l}\text { Boot and shoe manufacture and } \\
\text { repair }\end{array}$ & Leather dust, benzene or other solvent & $\begin{array}{l}\text { Leuk(a)emia, nose, paranasal sinus, } \\
\text { bladder }\end{array}$ \\
\hline Coal gasification & Coal tar, coal tar fume, PAHs & Skin, bladder, lung \\
\hline Coke production & Coal tar fume & Skin, lung (bladder, kidney) \\
\hline Furniture and cabinet making & Wood dust & Lung \\
\hline $\begin{array}{l}\text { Haematite mining (underground) } \\
\text { with exposure to radon }\end{array}$ & Radon, Silica & Lung \\
\hline Steel founding and casting & PAHs, silica, metal fume, formaldehyde & Lung \\
\hline Magenta production & $\begin{array}{l}\text { Magenta, o-toluidine, } 4,4 \text { '-methylenebis(2-methylaniline), } \\
\text { o-nitrotoluene }\end{array}$ & Bladder \\
\hline $\begin{array}{l}\text { Isopropyl alcohol manufacture } \\
\text { (strong-acid process) }\end{array}$ & Diisopropyl sulfate, isopropyl oil, sulfuric acid & Paranasal sinus, larynx, (lung) \\
\hline $\begin{array}{l}\text { Painter (occupational exposure } \\
\text { as a) }\end{array}$ & - & Lung (bladder, stomach) \\
\hline Rubber industry & Aromatic amine, solvent & $\begin{array}{l}\text { Bladder, (stomach, larynx, leuk(a)emia, } \\
\text { lung) }\end{array}$ \\
\hline
\end{tabular}

(Modified from sourced by International Agency for Research on Cancer (IARC), 2009. http://monographs.iarc.fr/ENG/Classification/crthgr01.php).

nols and chloroguaiacols, and a rise in the number of chlorine atoms in the compound from each group examined led to an increase in DNA bases damage [11]. 3-Nitrobenzanthrone (3-NBA) is a mutagenic and carcinogenic environmental pollutant found in diesel exhaust and urban air pollution. These effects were related to induced DNA damage and changes in cell signalling pathways. 3-NBA caused most DNA damage as judged by the amount of DNA adducts ( ${ }^{32} \mathrm{P}$-postlabelling assay), single strand(ss) DNA breaks and oxidative DNA lesions (Comet assay) detected [12]. Its exposure induced considerable DNA damage resulting in accumulation of cells in S-phase and a marked increase in apoptosis. Importantly, nitro-PAHs and amino-PAHs induced both quailtatively and quantitatively different effects on DNA damage, cell cycle alterations and cytotoxicity. These results indicated that certain nitro-PAHs have a considerable pro-inflammatory potential [13].

Silicon carbide ( $\mathrm{SiC}$ )-nanoparticle (NP) exposure cause reactive oxygen species production, glutathione depletion and inactivation of some antioxidant enzymes: glutathione reductase, superoxide dismutase, but not catalase [14]. Active and native bentonite particles (BPs) could induce significantly the oxidative stress on human B lymphoblast cells in vitro. The cytotoxic difference between active BPs and native BPs may be associated with the oxidative stress induced by BPs to a certain extent. The insoluble particle fractions may play a main role in the oxidative stress induced by BPs [15].

Potassium bromate $\left(\mathrm{KBrO}_{3}, \mathrm{~PB}\right)$ was shown to induce
ROS production (12.5 mM), GSH depletion (1.56 - 12.5 $\mathrm{mM}$ ) and 8-OH-dG formation (6.25 - $12.5 \mathrm{mM}$ ) in HepG2 cells. A significant increase was found in the range of $6.25-12.5 \mathrm{mM}$ in lysosomal membrane stability assay. However, under these PB concentrations, it was not able to detect the changes of mitochondrial membrane potential. These results suggest that PB exerts oxidative stress and genotoxic effects in HepG2 cells, possibly through the mechanisms of lysosomal damage, an earlier event preceding the oxidative DNA damage [16]. It was observed that vanadium(III) trioxide and vanadium(V) pentoxide produced DNA single-strand breaks at all of the concentrations $(1,2,4$, or $8 \mu \mathrm{g} / \mathrm{ml})$ and treatment times $(2,4$, or $6 \mathrm{~h})$ tested. The results show that the genotoxic effect of vanadium can be produced by any of its three oxidation states [17].

Cell death and DNA-damage induced by silver nanoparticles (AgNP-P) were prevented by Tiron and dimethyl thiourea that scavenge $\mathrm{O}_{2}^{--}$and $\mathrm{H}_{2} \mathrm{O}_{2}$, respectively. These findings demonstrated the role of ROS in the AgNP-induced cell death and DNA damage [18]. Serious concerns have been expressed about potential risks of engineered nanoparticles. The $200 \mathrm{~nm}$ AgNPs in particular appeared to cause a concentration-dependent increase in DNA-strand breaks in NT2 human testicular embryonic carcinoma cells [19]. The effects of ultra-fine carbon black particles on oxidative damage or inflammation were uncertain. The oxidative damage or inflammation with ultrafine carbon black particles and the coeffects with solvent coating to it were evaluated. The oxi- 
dative DNA damage with smaller size carbon black was increased than bigger one (the range with $500-30 \mathrm{~nm}$ ). The $0.1 \%$ methylcyclohexane increased the damage by binding with each carbon black (the dose range with 100 $\mathrm{ng} / \mathrm{mL}$ - $100 \mu \mathrm{g} / \mathrm{mL})$. It could cause DNA damage by promoting oxidative stress and inflammatory responses [20].

Tungsten alloys (WA) produces large amounts of reactive oxygen species, causes significant amounts of DNA damage within $24 \mathrm{~h}$ [21]. Cadmium (Cd) significantly induced a dose-dependent increase in DNA damage with statistically significant differences relative to controls; the superoxide dismutase and glutathione peroxidase activities were significantly decreased. Lipid peroxidation and protein carbonyl levels were significantly increased while glutathione and the total intracellular sulfhydryl groups were decreased showing clearly that an oxidative stress were generated by $\mathrm{Cd}$ [22]. The results indicate that cellular pro-oxidative stress induced by $\mathrm{Cd}$ is most likely mediated by disruption of redox homeostasis associated to a mishandling of redox-active transition metals and causes lipid and protein oxidation and oxidative DNA damage in vitro.

The $\mathrm{TiO}_{2}$ NPs dispersion with large agglomerates (3min sonication and no serum in stock solution) induced DNA damage in all three cell lines. An increased level of DNA oxidation lesions detected in Cos- 1 and TK6 cells indicates that the leading mechanism by which $\mathrm{TiO}_{2} \mathrm{NPs}$ trigger genotoxicity is most likely oxidative stress [23]. A significant LDH release was found only for MWCNTs, the significant apoptosis induction was found from 10 $\mu \mathrm{g} / \mathrm{ml}$ of MWCNT-OH. A concentration-dependent increase of direct DNA damage, significant at $40 \mu \mathrm{g} / \mathrm{ml}$ of MWCNTs and begin from $5 \mu \mathrm{g} / \mathrm{ml}$ of MWCNT-OH was detected. Oxidative DNA damage was not observed for both CNTs [24].

There was a dose-effect relationship between the organic extract of coke oven emissions (OE-COE) and the direct DNA damage presented by tail length, tail intensity and tail moment in the Comet assay. The presence of lesion-specific endonucleases in the assays increased DNA migration after OE-COE treatment when compared to those without enzymes, which indicated that OE-COE produced oxidative damage at the level of pyrimidine and purine bases. It was indicated that OE-COE exposure can induce DNA breaks/oxidative damage and genomic instability in vitro [25]. The FPG-Comet assay appears more specific for detecting oxidative DNA damage induced by complex mixtures of genotoxic substances.

It has some advantages and disadvantages with using in vitro system. With aritificial redox reaction systems, it is mostly inexpensive, fast and provides information about radical specificity, but it could get no information about biological effects if effects take place intracellulary.
Subcellular fractions could get no informations concerning the metabolism and bioavailability of the antioxidants if effects take place intracellulary. Experiments with intact cells, it could get only partial information on intracellular effects, metabolism and signaling pathways only partly reflected, could get no information on absorbtion and on organ specific effects and limited information about bioavailability [26].

\section{RECENT IN VIVO OXIDATIVE DNA DAMAGES WITH INDUSTRIAL CHEMICALS}

\subsection{Experimental Studies with Lab Animals}

To clarify whether a kind of DNA damage from ROS is involved with its potential health hazards, it was measured the DNA damage through Fpg/Endo III FLARE (Fragment Length Analysis with Repair Enzyme) assay with cynomolgus monkeys. The FLARE assay was suggested as being available as a biological tool for DNA damage induced by welding fume exposure in cynomolgus monkeys [27]. And the DNA damage through Fpg/ Endo III FLARE assay was measured to clarify the DNA damage from cumene exposure. This assay was suggested as being available as a biological marker for DNA damage induced by cumene exposure in SD rats. It provided the evidence that cumene exposure may cause suppression of rOGG1 in the rat hepatocytes or lymphocytes [28]. Thus, the Comet assay is one of the most common methods used to measure oxidatively damaged DNA in peripheral blood mononuclear cells (PBMC), as a biomarker of oxidative stress in vivo. Modifications to the alkaline Comet assay by using lesion-specific endonucleases, such as formamidopyrimidine-DNA glycolsylase (FPG) and endonuclease III (ENDOIII, also known as Nth), can detect DNA bases with oxidative damage.

Fenofibrate (FF), a peroxisome proliferator-activated receptor-alpha agonist, induces oxidative stress and promotes hepatocarcinogenesis in the liver of rodents. It belongs to a class of non-genotoxic carcinogens, but DNA damage secondary to oxidative stress resulting from ROS generation is suspected in rodents given this chemical. In the Comet assay, it was suggested that the FF causes some DNA damage in livers of rats, but is not a strong genotoxic substance leading to a DNA mutation since such DNA damage was repaired by the increased activity of some DNA repair genes [29]. With the systemic organophosphorus insecticide, phorate [O,Odiethyl S-[(ethylthio) methyl] phosphorothioate], the biochemical analysis of catalase and glutathione revealed significantly lesser activities of antioxidative enzymes and lipid peroxidation in tissues of phorate exposed rats. Furthermore, generation of intracellular reactive oxygen 
species and reduced mitochondrial membrane potential in bone marrow cells confirmed phorate-induced oxidative stress [30]. A kind of per- and polyfluorinated compounds (PFCs), the PFNA associated increase in DNA single strand breaks (SSBs) was attributed to a subpopulation of moderately damaged possibly associated with cytotoxicity in primary rat testicular cells. No significant increase in oxidative DNA damage was measured for any of the PFCs [31].

The cytogenetic alterations in leukocytes observed in workers occupationally exposed to styrene can induce DNA damages. Main route of exposure to these compounds is inhalation, in the presence of the formamidopyridine DNA glycosylase, an enzyme able to recognize and excise DNA at the level of some oxidized DNA bases, a significant increase of DNA damages was observed at the end of the 3rd day of treatment in leukocytes from rats exposed to styrene but not to styrene7,8-oxide [32].

As the above, it has some advantages and disadvantages with using in vivo system. With animal studies, it enable to monitor organ specific effects reflect absorption and metabolism, but some mammalian/ROS-models reflect the situation in humans inadequately. It was shown the commonly used strategies for the detection of oxidative DNA damage efficiently in Table 2.

\subsection{Field Studies with Workers}

With human studies, they provide informations concerning absorption and metabolism in humans, most experiments are conducted with lymphocytes or plasma, urine which provide less information on effects in inner organs. It requires to establishing controlled conditions in intervention trials.

A study of pesticide applicators and farmworkers was conducted to examine the relationship between organophosphate pesticide exposure and biomarkers of oxidative DNA damage. 8-OH-dG levels were 8.5 times and 2.3 times higher in farmworkers or applicators (respectively) than in controls. DNA damage (Comet assay) and oxidative DNA repair were significantly greater in lymphocytes from applicators and farmworkers when compared with controls. The findings from these studies indicate that organophosphate pesticides induce oxidative DNA damage in agricultural workers [33]. A study of horticultural farmers exposed to organophosphate pesticides (OPs) and controls investigated the relationships between OP exposure and oxidative DNA damages. They had higher DNA damage than the controls and there was a significant positive relationship between dialkylphosphate (DAP) and DNA damage with greater than 95\% power. The farmers also had a significant positive relationship between urinary DAP and 8-OH-dG levels [34]. Oxidative DNA damages have been proposed as mecha- nisms linking pesticide exposure to health effects such as cancer and neurological diseases. The data obtained from the evaluation of subjects occupationally exposed to pesticide mixtures from Santa Fe province, Argentina, the results showed modifications in lipid peroxidation, antioxidant defence system, and DNA damage in lymphocytes of exposed workers [35].

As silica particles and metals are important occupational hazards in foundry workers, the exposure may result in DNA damage and lipid peroxidation through oxidative stress [36]. A higher risk for oxidative DNA damage lesions was also found in occupationally PAHexposed groups. A higher concentration of hydroxy- pyrene (1-OHP) was found in the exposed group $(0.322 \pm$ $0.289 \mu \mathrm{g} / \mathrm{g}$ creatinine) relative to the control group $(0.178 \pm 0.289 \mu \mathrm{g} / \mathrm{g}$ creatinine $)$. Moreover, higher levels of 1-OHP were found in workers involved in manufacturing processes $(0.346 \mu \mathrm{g} / \mathrm{g}$ creatinine $)$ compared to administrative workers $(0.018 \mu \mathrm{g} / \mathrm{g}$ creatinine $)$ [37].

DNA integrity was investigated in the lymphocytes of 50 bus drivers, 20 garagemen and 50 controls using the Comet assay with excision repair enzymes. Both exposed groups exhibited higher levels of DNA instability and oxidative damage to biological macromolecules than the controls. The incidence of oxidized lesions in lymphocyte DNA, but not the urinary levels of 8-oxodG, correlated with exposure to benzene and triglycerides increased this damage [38]. Many studies have reported an increase of DNA damage is related to hazardous exposure of municipal waste incinerators. Higher tail moment value was found in workers at fly ash treatment plants (7.55) than in the workers in bottom ash plants (2.64), as well as those in blue collar was higher than in white collar workers (5.72 vs. 3.95) [39]. The lead $(\mathrm{Pb})$ exposure associated oxidative stress was also studied. The results indicated that the exposed workers had a significantly higher mean tail length than that of controls. The levels of antioxidant enzymes were relatively reduced $(\mathrm{P}>0.05)$ while the rate of lipid peroxidation was higher in the exposed subjects [40].

A significant negative correlation was observed between SSBs and styrene concentration at workplace $(\mathrm{R}=$ -0.38 ); SSBs were also significantly higher in men. The capacity to repair irradiation-induced DNA damage was the highest in the low exposure group (1.34 \pm 1.00 $\left.\mathrm{SSB} / 10^{9} \mathrm{Da}\right)$, followed by high exposure group $(0.72 \pm$ $\left.0.81 \mathrm{SSB} / 10^{9} \mathrm{Da}\right)$ and controls $\left(0.65 \pm 0.82 \mathrm{SSB} / 10^{9} \mathrm{Da}\right)$. The mRNA expression levels of XRCC1, hOGG1 and $X P C$ were negatively correlated with styrene concentrations in blood and at workplace and positively with SSBs [41]. It was investigated the effect of the seasonal variability of environmental air pollutants on oxidative stress in a group of 59 city policemen. 8-oxodG levels were significantly increased by exposure to PM2.5 over a 
Table 2. Commonly used detection strategies for oxidative DNA damages.

\begin{tabular}{|c|c|c|}
\hline Strategy & Description & Reference \\
\hline $\begin{array}{l}\text { PCR (Polymerase Chain } \\
\text { Reaction) }\end{array}$ & $\begin{array}{l}\text { It is one of the most reliably used techniques for detecting } \\
\text { DNA damage as the amplification stops at the site of the } \\
\text { damage. }\end{array}$ & $\begin{array}{l}\text { Rochette } \text { et al. Photochem Photobiol 2006; 82: 1370-6/ } \\
\text { Kumar et al. Biochem Biophys Res Comm } \\
\text { 2004; 318: 1025-30/Karakoula et al. J Immunol Meth } \\
\text { 2003; 277: 27-37. }\end{array}$ \\
\hline Comet assay & $\begin{array}{l}\text { It is used to detect mainly single-strand break, double-strand } \\
\text { break, oxidative DNA damage and single- strand break } \\
\text { associated with incomplete excision repair sites caused by } \\
\text { UV radiation, ultrasound, electromagnetic frequency } \\
\text { radiation etc. }\end{array}$ & $\begin{array}{l}\text { Heepchantree et al. J Toxicol Environ Health A } \\
\text { 2006; 69: 1071-82/Olive and Banath. Int J Radiat Biol 1993; } \\
\text { 64: 349-58; Radiat Res 1995; 142: 144-52/Singh et al. Exp } \\
\text { Cell Res 1988; 175: 184-91/Olive } \text { et al. Exp Cell Res 1992; } \\
\text { 198: 259-67/Tiano et al. Biofactors 2005; 25: 187-95/Morley } \\
\text { et al. Mutagenesis 2006; 21: 105-14. }\end{array}$ \\
\hline
\end{tabular}

Halo assay

TUNEL assay

HPLC-Electrospray tandem mass spectrometry

FISH

Flow cytometry (FCM)

Annexin V labeling

Immunological assay including immunofluorescent and chemiluminescence thymine dimer detection

Immunohistochemical assay

ELISA
It can measure single cells and does not require radioactive labeling of DNA. It was used to detect the alterations in DNA organization in individual cell.

It detects DNA fragmentation by fluoresceinating the free ends of the DNA and it can also detect single and double-strand breaks.

A urinary-8-hydroxylated species of guanine has been determined by using this assay. It is used to quantify 5,6-dihydroxy-5,6-dihydrothymidine, 5-hydro-xy-2-deoxyuridine,

8-oxo-7,8-dihydro-2-deoxyadenosine in isolated and cellularDNA after exposure to $\gamma$-rays.

With this technique, visualization and estimation of DNA damage is carried out on a cell by cell basis. Chromosomes with numerical aberrations are detected efficiently by this method.

It is useful in detecting chromosomal aberrations, sister-chromatid exchange, chemical adducts to DNA and DNA strand breakage. Recently, nucleotide excision repair has been also detected by alkaline unwinding FCM assay.

DNA fragmentation is only detected in annexin V-positive cells. Vital cell are negative for both propidium iodide and annexin $\mathrm{V}$, apoptotic cells are negative for propidium iodide and positive for annexin $\mathrm{V}$ whereas dead cells are positive for both propidium iodide and annexin V. Apoptosis in tumors cells caused by X-rays has been recently detected by using (125)I-radiolabeled annexin V.

It is also one of the methods commonly used for the detection of oxidative DNA damage but it has limitations because of cross-reactivity of the antibodies with normal DNA bases. In this assay DNA damage can be detected and quantified very efficiently by immunoslot-blot system utilizing chemiluminescent detection. Immuno-slot-blot assay is used to detect very low levels of adduct in very small amount of DNA.

It is applicable to small amount of samples and detect adducts in specific cell types within the tissue. It is useful for in vitro and in vivo studies on cancer, oxidative stress-associated pathologic conditions such as ageing, neurodegenerative diseases, ischemia-reperfusion injury etc.

In this technique antigens (modified DNA) bound to the plate which is blocked by the incubation of wells with a dilute protein solution. Thereafter, unknown samples are similarly mixed with antibody before addition to the plate. Bound primary antibody is quantified with enzyme-conjugated secondary antisera by addition of appropriate substrate after incubation and washing off non-bound material.
Sestili et al. Mutat Res 2006; 607: 205-14.

Pulkkanen et al. Apoptosis 2000; 5: 329-33/Pietruszewska et al. Otolaryngol Pol 2005; 59: 837-42/Stecco et al. Ital J Anat Embryol 2005; 110: 255-60.

Douki et al. J Biol Chem 2000; 275: 11678-85/Frelon et al. Chem Res Toxicol 2000; 13: 1002-10.

Murthy and Demetrick. Methods Mol Biol 2006; 319: 237-59/ Sidoni et al. Anticancer Res 2006; 26: 2333-7/Qian et al. J Experim Hematol 2006; 14: 577-81.

Thyagarajan et al. Mutagenesis 2007; 22: 147-53.

Watanabe et al. Nucl Med Commun 2006; 27: 81-9.

Müller et al. Free Radic Res 2004; 38: 1093-100/Perdiz et al.

J Biol Chem 2000; 275: 26732-42/Sinha et al. Acta Protozool 2001; 40: 187-95/Otero et al. Photochem Photobiol Sci 2006; 5: 760-9.

Santella. Cancer Epidemiol Biomarkers Prev 1999; 8: 733-9/ Toyokuni et al. Lab Invest 1997; 76: 365-74.

Santella, Cancer Epidemiol Biomarkers Prev 1999; 8: 733-9. 


\section{Continued}

\begin{tabular}{|c|c|c|}
\hline RIA & $\begin{array}{l}\text { It has the capacity to estimate } 6-4 \text { photoproducts and } \\
\text { cyclobutane dimers in DNA. In the detection of very low } \\
\text { quantity of cyclobutane pyrimidine dimer (CPD) in } \\
\text { bacterioplankton and marine viruses caused by UV-B } \\
\text { radiation, radioimmunoassay was found to be very effective. } \\
\text { Specific RIAs were used to monitor antibody binding sites } \\
\text { associated with cyclobutane dimers and 6-4 photoproducts. }\end{array}$ & $\begin{array}{l}\text { Jeffrey et al. Photochem Photobiol 1996; 64: 419-27/Miller } \\
\text { et al. ASM News 1999; 65: 535-41. }\end{array}$ \\
\hline $\begin{array}{l}\text { Gas chromatography-mass } \\
\text { spectropmetry and } \\
\text { electrochemical methods }\end{array}$ & $\begin{array}{l}\text { For the detection of oxidative DNA damage, GC-MS is } \\
\text { commonly used because of its ability to detect wide range } \\
\text { of DNA base product. But this method sometimes } \\
\text { overestimate the oxidative damage due to the derivatization } \\
\text { of hydrolyzed DNA at higher temperature in the presence } \\
\text { of air that result in increase level of 8-OH-guanine, } \\
\text { 8-OH-adenine and 5-OH-cytosine. 8-oxo-7,8-dihydroguanine } \\
\text { is the most common type of base damage. Fapy } \\
\text { (formamido-pyrimidines) derivatives are also measured } \\
\text { by the use of GC-MS. }\end{array}$ & $\begin{array}{l}\text { Jenner et al. Biochem J 1998; 331: 365-9/Douki et al. J } \\
\text { Chem Soc Perkin Trans 1999; 2: 1875-80/Radiat Res } \\
\text { 2000; 151:29-35. }\end{array}$ \\
\hline
\end{tabular}

(Modified from sourced by Kumari et al.: Detection of DNA damage. EXCLI Journal 2008; 7: 44-62).

2-day period before sampling and by exposure to $\mathrm{B}[\mathrm{a}] \mathrm{P}$ over a 28-day period, days 57-84 before sampling. These results indicate that the exposure to environmental pollutants affects urinary excretion of 8 -oxodG, lipid peroxidation and the frequency of chromosomal aberrations [42]. The paints exposed group showed higher hippuric acid and delta-aminolevulinic acid levels (friday samples) and lower superoxide dismutase activity (monday samples) in relation to control group. DNA damage index (Comet assay) was higher in the exposed group, both in monday and friday samples, compared to the control group [43]. The results suggest that individuals exposed to paints have increased levels of DNA damage.

To investigate associations between occupational exposure to cooking oil fumes (COFs) and potential oxidative and genotoxic effects in kitchen workers. Occupational exposure to COFs led to increased oxidative damage in Chinese kitchen workers. Urinary 1-OHP and 8-oxodG are noninvasive and effective biomarkers for assessment of oxidative damage in restaurants workers [44]. It was indicated that the genetic damage was detectable in road paving workers occupationally exposed to bitumen and also demonstrate the high sensitivity of Comet assay to assess early oxidative effects induced by exposure to bitumen fumes at low doses and confirm the suitability of urinary 1-OHP as a biomarker of PAH exposure [45]. Sewage workers are exposed to multiple chemicals among which many are suspected genotoxicants. Therefore, they might incur oxidative DNA damage [46]. Significantly higher levels of 8-oxodGuo adducts and DNA strand breaks were found in both preand post-shift blood samples of exposed workers compared to those of the referents. No positive associations between DNA damage and magnitude of airborne exposure to vapours and aerosols of bitumen could be observed in this study. It was indicated the increased oxida- tive DNA damage in workers exposed to vapours and aerosols of bitumen compared to non-exposed referents at the group level [47].

The occupational workers were continuously exposed to mixture of pirimiphos methyl, chlorpyrifos, temephos and malathion on a regular interval as per usage and activity. The Comet assay using lymphocytes of exposed workers showed significantly higher mean comet tail DNA \% value $(60.43 \%$ vs. $31.86 \%)$ and tail moment (TM) value $(14.48 \mu \mathrm{m}$ vs. $6.42 \mu \mathrm{m})$ in occupational workers as compared to controls. These results suggest that the exposure to mixture of pirimiphos methyl, chlorpyrifos, temephos and malathion may induce DNA damage [48]. It was investigated the role of oxidative processes in the genotoxicity associated with exposure to waste anaesthetic gases. The ROS generation and plasma and urine concentrations of thiobarbituric acid-reacive substances (TBARS) and 8-iso-prostaglandin $\mathrm{F}_{2 \alpha}$ (8-iso$\mathrm{PGF}_{2 \alpha}$ ), respectively, were elevated, while glutathione peroxidise (GPX) activity was reduced in nurses exposed to waste anaesthetic gases. Occupational exposure to $\mathrm{N}_{2} \mathrm{O}$ is associated with increased oxidative DNA damage and the level of exposure plays a critical role in this regard. Increased oxidative stress may represent a mechanistic link between chronic $\mathrm{N}_{2} \mathrm{O}$ exposure and genotoxicity [49].

\section{CHEMOPREVENTION OF OXIDATIVE DNA DAMAGES FOR WORKERS' HEALTH}

DNA repair is an essential cellular function, which, by removing DNA damage before it can cause mutations, contributes crucially to the prevention of cancer. Micronutrients can influence DNA repair, usually but not always enhance activity. Different modes of DNA repair are likely to be subject to different regulatory mecha- 
nisms.

Phytochemical compounds present in legumes have gained a lot of interest because of their possible chemopreventive agents. They exerted significant protective activity against free radical-induced DNA damage. This activity was more potent against ROO radical-induced DNA damage than against that induced by $\mathrm{OH}$ radicals. It was implied that these phenolic compounds may act as chemopreventive agents [50]. The generation of ROS in the body from carcinogen, mutation and DNA damage in cancer is protected by natural antioxidants (phytochemicals) with antimutagenic effect. The chromosomal aberration (CA) test and Comet assay were used to evaluate the anti-genotoxicity of ginsenoside $\mathrm{Rb}_{1}$ and $\mathrm{Rg}_{1}$, in CHO-K1 (Chinese hamster ovary fibroblast) cell in vitro. In the Comet assay, the tail moment values were decreased in all the $R b_{1}$ and $R g_{1}$ treated groups. So the ginsenoside $\mathrm{Rb}_{1}, \mathrm{Rg}_{1}$ are thought as an antioxidant phytochemicals to protect mutagenicity [51]. Antioxidant activity of Acacia salicina extracts was determined to protect against DNA strand scission induced by hydroxyl radicals. Protection against methylmethanesulfonateinduced mutagenicity was observed for total oligomer flavonoids (TOF), methanol, and ethyl acetate extracts [52]. It was indicated that instant decaffeinated coffee (IDC) and chlorogenic acid (5-O-caffeoylquinic acid; CGA) protect PC12 cells from $\mathrm{H}_{2} \mathrm{O}_{2}$-induced apoptosis by blocking the accumulation of intracellular ROS and the activation of MAPKs [53]. The 50\% methanolic extracts obtained from different plant parts contained significant amounts of polyphenols with superior antioxidant activity as evidenced by the scavenging of several radicals. C. icosandra, R. damascena and C. scariosus showed significant potential for preventing oxidative DNA damage and radical scavenging activity [54].

The blood samples of the endemic regions showed severe DNA damage with increased levels of ROS and lipid peroxidation. Three months curcumin intervention reduced the DNA damage, retarded ROS generation and lipid peroxidation and raised the level of antioxidant activity. Thus curcumin may have some protective role against the DNA damage caused by arsenic [55]. Chemoprevention to protect the normal cells from the conversion to cancer cells using safe chemicals is becoming popular as an effective strategy to conquest the cancer. It is focused on many industrial chemicals that induce the oxidative DNA damages which workers are exposed to and the preventive effects of phytochemicals in each stage of damages, and the relationship between the phytochemicals and the expression of the enzymes.

Pre-treatment with Opuntia ficus indica f. inermis methanolic flowers extract (OMFE) at oral doses 250, 500 and $1000 \mathrm{mg} / \mathrm{kg}$ body weight was found to provide a dose-dependent protection against ethanol-induced gas- tric ulcer by averting the deep necrotic lesions of the gastric epithelium, by preserving normal antioxidant enzymes activities, by inhibiting the lipid peroxidation, the oxidation of protein and the DNA fragmentation in gastric mucosa [56].

Some of the isolated compounds like phenylethanoid derivatives showed stronger antioxidant capacity than trolox and were also able to significantly inhibit $\beta$-galactosidase induction caused by the mutagen agent nitrofurantoin [57]. It was conducted to evaluate the ability of aqueous and ethanolic extracts of four Fabiana species to inhibit key enzymes in inflammatory processes, free radical scavenging properties and genotoxic effects. Fabiana bryoides ethanolic extract showed an interesting effect: it inhibited spontaneous mutagenesis, which could be considered as an antimutagenic effect in the TA98 $(+$ S9) and TA100 (+S9/-S9) strains [58]. A possible protective effect of fish oil against oxidative damage promoted by methylmercury (MeHg) in sub-chronically exposed rats was evaluated. Methylmercury exposure was also associated with DNA damage. A significant DNA protective effect (about 30\%) was observed with fish oil treatment. It was demonstrated the oxidative damage even after low-level $\mathrm{MeHg}$ exposure and the protective effect of fish oil [59].

An evident accumulation of $\mathrm{Cr}$ in peripheral red blood cells was accompanied by a significantly decreased serum folate in chromate exposed workers. The decreased serum folate was associated with an increased urinary 8-hydroxy-2'-deoxyguanosine, DNA strand breaks and global DNA hypomethylation. These findings suggest that chronic occupational chromate exposure could induce folate depletion, which may further promote DNA damages and global DNA hypomethylation [60]. It was shown that activity of antioxidant enzymes of plasma and brain tissue and total antioxidant capacity in plasma decreased significantly due to oxidative stress generated by $\mathrm{MeHgCl}$. Administration in higher dose of both kind of linolenic acid restored all the activities of the antioxidant enzymes and also reduced lipid peroxidation and increased total antioxidant capacity in plasma. $\alpha$-Linolenic acid was more efficient antioxidant than $\alpha$-eleostearic acid against oxidative DNA damage [61].

The reduced form of $\mathrm{CoQ}_{10}$ (ubiquinol, $\mathrm{Q}_{10} \mathrm{H}_{2}$ ) is an effective antioxidant in biological membranes. With regard to several studies, $\mathrm{CoQ}_{10}$ provides protective effects on several markers of oxidative DNA damage and genomic stability [62]. Vitamin C supplementation decreased the frequency of chromosomal aberrations in groups with insufficient dietary intake who were occupationally exposed to mutagens. The prevalence of DNA adducts inversely correlated with vitamin $\mathrm{C}$ levels in groups environmentally exposed to high concentrations of c-PAHs. Increased vitamin $\mathrm{C}$ levels decreased DNA 
strand breakage induced by air pollution. The 8-oxodG levels were decreased by vitamin $C$ supplementation [63]. Several epidemiological and experimental studies have been reported that lutein (LT) presents antioxidant properties. The protective effects of LT against oxidative DNA damage induced by cisplatin (cDDP) in a human derived liver cell line (HepG2) were investigated. The results indicate that cDDP induces pronounced oxidative stress in HepG2 cells that is related to DNA damage and that the supplementation with the antioxidant LT may protect these adverse effects caused by the exposure of the cells to platinum compound [64].

Resveratrol (3,5,4'-trihydroxy-trans-stilbene; RV) is a naturally occurring polyphenol widely distributed in food and dietary plants. The dietary phytochemical resveratrol has become a focus of intense research owing to its roles in cancer prevention. At the stage of DNA damage formation, RV protects the genome as an antioxidant via inhibition of inflammation, suppression of metabolic carcinogen activation, de novo expression of genes that encode detoxifying proteins and possibly even via radical scavenging properties [65]. RV inhibited cell proliferation, generated ROS, and caused DNA SSBs. Most of the up $\&$ down-regulated proteins obtained from the 2D gel electrophoresis were identified as apoptosis-related proteins. It also regulated the expression of proteins involved in the redox pathways and apoptosis [66]. It was observed that RV acts as a potent 5-lipoxygenase (5LOX) inhibitor obtained from natural sources. The result indicated that RV is a strong antioxidant in reduceing lipid peroxidation and preventing DNA damage. It significantly decreased the extent of DNA strand break and also induced apoptosis in carcinogen-challenged rat mammary tissue. Moreover, RV also activated the base excision repair (BER) system in mRNA and protein levels in DNA auto-repair process [67].

The study investigated the protective effects of green tea polyphenols (GTPP) on tributyltin (TBT)-induced oxidative damage. The possible protective mechanism may be due to the powerful ability of GTPP to scavenge ROS and prevent DNA breaks [68]. The protective action from orally administered ellagic acid (EA), benzyl isothiocyanate (BITC), an extract of epigallocatechins $\left(\right.$ Tegreen ${ }^{B}$ ) as well as chlorophyllin (CHL) against benzo[a]pyrene (B[a]P)-induced DNA damage and cytogenetic effects was investigated. In Comet assay, $\mathrm{CHL}$ or EA caused a 3-fold decrease of SSB, and a 2-fold decrease of FPG sites in comparison to animals treated with B[a]P [69]. Pre-incubation with low micromolar level polyphenols, quercetin or rutin can significantly attenuate DNA damage in cell lines, indicating that the polyphenols did not work through an enzymatic mechanism. The inhibitory effect of polyphenols has to be assigned to non-enzymatic repair mechanism rather than to enzy- matic repair mechanism or antioxidant mechanism [70]. Pre-treatment with mangiferin (MGN) significantly inhibited MeHg-induced DNA damage. Also, pre-treatment with MGN significantly reduced MeHg-induced oxidative stress. MGN pre-treated cells demonstrated a significant increase in the GSH and GST levels followed by a significant decrease in malondialdehyde (MDA) formation. These are indicated the protective effect of MGN against MeHg. Anti-lipid peroxidative potential plausibly because of its free radical scavenging ability, reduced the oxidative stress [71]. Oral administration of Pu-erh black tea extract (PBTE) effectively suppressed, urinary 8OH-dG and DNA damage in isolated renal cells, amelioration of oxidative stress and modulation of antioxidative system. PBTE administration ameliorated QCTinduced nephrotoxicity by mitigating oxidative stress [72]. It was shown the typically used chemopreventive phytochemicals and their dietary sources in Table 3.

\section{DISCUSSION}

Free radicals and other reactive species are constantly generated in vivo and cause oxidative damage to DNA at a rate that is probably a significant contributor to the development of cancer. Measurement of 8-hydroxylated guanine is the commonest method of assessing DNA damage, but there is no consensus on what the true levels are in human DNA [73].

A variety of biomarkers have been used to monitor exposed populations to determine potential health hazards from their exposure to toxic agents in workplaces. However, the majority of these biomarkers have been focused onto the identification of biological damage from the exposure. Therefore, there is a need to develop functional biomarkers that can identify exposure-induced functional deficiencies. More importantly, these deficiencies should be positioned along pathways that are responsible for the development of specific diseases. The challenge assay has been used in different laboratories to show that a variety of exposed populations (with exposure to air pollutants, chemicals at work) expressed abnormal challenge response. The predicted health conesquences of some of these studies have also been validated [74]. 8-OH-dG, DNA strand breaks and DNA repair capacity were measured as biomarkers of early effects of carcinogenic compound exposure. The urinary S-phenylmercapturic acid (S-PMA) and DNA damage by the Comet assay were both sensitive to exposure to low levels of benzene, and glutathione (GSH) seems to play an important defence role against benzene-dependent DNA damage [75].

Genetic polymorphisms are increasingly recognized as sources of variability not only in toxicokinetic but also in toxicodynamic response to environmental agents. However, the implications for risk assessment are limited by 
Table 3. Typically used chemopreventive phytochemicals and their dietary sources.

\begin{tabular}{|c|c|c|}
\hline Phytochemical & Dietary source & Functions related oxidative stress \\
\hline Curcumin & Turmeric & $\begin{array}{l}\text { Curcumin has carcinogenic and pro-oxidant effects may be seen in addition to } \\
\text { anticancer and antioxidant effects. }\end{array}$ \\
\hline Resveratrol & Grapes & $\begin{array}{l}\text { Resveratrol increased intracellular glutathione levels which protected them against } \\
\text { cigarette smoke extract-induced oxidative stress. }\end{array}$ \\
\hline Capsaicin & Chilli peppers & $\begin{array}{l}\text { Capsaicin-induced apoptosis was in association with the elevation of intracellular } \\
\text { reactive oxygen species production. It has potential as a novel therapeutic agent for } \\
\text { the treatment of leukemia. }\end{array}$ \\
\hline Caffeic acid phenethyl ester (CAPE) & Honey & $\begin{array}{l}\text { It is known to have antimitogenic, anticarcinogenic, anti-inflammatory, and } \\
\text { immunomodulatory properties in vitro. Another study also showed that CAPE } \\
\text { suppresses acute immune and inflammatory responses and holds promise for } \\
\text { therapeutic uses to reduce inflammation. }\end{array}$ \\
\hline [6]-Gingerol & Ginger & $\begin{array}{l}\text { [6]-Gingerol appeared to inhibit/intervene sodium arsenite(iAs) induced } \\
\text { cyto-degeneration of pancreatic } \beta \text {-cells and hepatocytes, helped in scavenging the } \\
\text { free radicals. }\end{array}$ \\
\hline Diallyl sulphide & Garlic & $\begin{array}{l}\text { It significantly increases the production of the enzyme glutathione S-transferase } \\
\text { (GST), which binds electrophilic toxins in the cell. Garlic protects nerve cells from } \\
\text { oxidative stress, also in vitro. }\end{array}$ \\
\hline Epigallocatechin-3-gallate (EGCG) & Green tea & $\begin{array}{l}\text { The protective effect of EGCG may in part be a consequence of the reduction in } \\
\text { oxidative stress and the pro-inflammatory response. }\end{array}$ \\
\hline Indole-3-carbinol & Cabbage & $\begin{array}{l}\text { Indole-3-carbinol is an AhR activator and enhances microsomal ROS production } \\
\text { resulting in the upregulation of Nrf2 gene batteries. }\end{array}$ \\
\hline Genistein & Soybeans & $\begin{array}{l}\text { Geinstein do a direct antioxidation with some proxidative features and activation } \\
\text { of Nrf } 2 \text { antioxidative response }\end{array}$ \\
\hline Sulphoraphane & Broccoli & $\begin{array}{l}\text { Sulforaphane is a promising antioxidant agent that is effective to attenuate } \\
\text { oxidative stress and tissue/cell damage in different in vivo and in vitro } \\
\text { experimental paradigms. }\end{array}$ \\
\hline Lycopene & Tomatoes & $\begin{array}{l}\text { Lycopene can be accessible for other benefits such as antioxidation. Lycopene } \\
\text { is also the most efficient oxygen and free radical quencher. Lycopene also may } \\
\text { help decrease the impact of oxidative load from pylori infections in the stomach. }\end{array}$ \\
\hline
\end{tabular}

(Modified from Sourced by Young-Joon Surh. Nature Reviews Cancer 2003; 3: 768-780).

the likelihood that polymorphisms in multiple BER genes interact to modulate DNA repair [76]. Emerging evidence suggests that mitochondrial (mt) DNA damage may be a trigger for apoptosis in oxidant-challenged pulmonary artery endothelial cells (PAECs). Understanding the rate-limiting determinants of mtDNA repair may point to new targets for intervention in acute lung injury. One of the key BER enzymes is Ogg1, which excises the base oxidation product 8-oxoguanine. It was suggested that Ogg1 plays a critical and possibly rate-limiting role in defending PAECs from oxidant-induced apoptosis by limiting the persistence of oxidative damage in the mitochondrial genome [77]. It was indicated that the PON1 and $C Y P 2 D 6$ genotypes can modulate DNA damage elicited by some organophosphate pesticides (OPs) possibly through gene-environment interactions [78]. Oxidatively damaged DNA base lesions are considered to be mainly repaired by 8-oxoguanine DNA glycosylase (OGG1) mediated pathways. The effect of the OGG1 Ser326Cys polymorphism on the level and repair of oxi- datively damaged DNA in mononuclear blood cells (MNBC) by means of the Comet assay were investigated. It was indicated that the OGG1 Ser326Cys polymerphism has limited influence on the DNA repair incisions by extracts of MNBC, whereas the apparent increased risk of cancer in subjects with the Cys/Cys genotype may be because of higher levels of oxidatively damaged DNA [79]. DNA repair of oxidative damage should therefore play a pivotal role in defending humans against cancer. It is focused on the most common and widely studied single nucleotide polymorphisms (SNPs) of oxidative DNA damage repair proteins trying to bridge the information available on biochemical and structural features of the repair proteins with the functional effects of these variants and their potential impact on the pathogenesis of disease [80]. With molecular studies, the ROS constantly attack DNA. It was shown that the E3 ligase Mule can ubiquitinate and degrade Pol $\lambda$, and that the control of Pol $\lambda$ levels by Mule has functional consequences for the ability of mammalian cells to deal with 8-oxo-G lesions. 
In contrast, phosphorylation of Pol $\lambda$ by $\mathrm{Cdk} 2 /$ cyclinA counteracts this degradation by recruiting it to MutYH on chromatin to form active 8-oxo-G repair complexes [81]. The 8-oxoGua is an abundant and mutagenic lesion excised by oxoguanine DNA glycosylase 1 (OGG1) and measurable in urine or plasma by chromatographic methods with electrochemical or mass spectrometric detectors, reflecting the rate of damage in steady state. A common genetic OGG1 variant may affect the activity and was associated with increased levels of oxidized purines in leukocytes without apparent effect on 8-oxoGua excretion or major change in cancer risk. One prospective study found increased risk of developing lung cancer among non-smokers associated with high excretion of 8-oxoGua. Urinary excretion of 8-oxoGua is a promising biomarker of oxidatively damaged DNA [82]. Glutathione S-transferases (GSTs) are members of a multigene family of isoenzymes that are important in the control of oxidative stress and in phase II metabolism. It was shown that GST polymorphisms and GST activity can apparently influence DNA stability and repair of oxidised bases, suggesting a potential new role for these proteins in DNA damage processing via DNA damage signalling [83].

In this review I have summarized information on more than 80 references, most of which were published in last three years, it is suggested that some shortcomings associated with biomarkers, along with gaps in our knowledge, may be responsible for the failure to produce consistent and definitive results when applied to understanding the role of oxidative DNA damage in disease, highlighting the need for further studies.

\section{REFERENCES}

[1] Evans, M.D. and Cooke, M.S. (2004) Factors contributing to the outcome of oxidative damage to nucleic acids. BioEssays, 26, 533-542. doi:10.1002/bies.20027

[2] Valko, M., Morris, H. and Cronin, M.T. (2005) Metals, toxicity and oxidative stress. Current Medicinal Chemistry, 12, 1161-1208. doi:10.2174/0929867053764635

[3] Lee, J.C., Son, Y.O., Pratheeshkumar, P. and Shi, X. (2012) Oxidative stress and metal carcinogenesis. Free Radical Biology \& Medicine, 53, 742-757.

doi:10.1016/j.freeradbiomed.2012.06.002

[4] Swaran, J.S.F. (2011) Arsenic-induced oxidative stress and its reversibility. Free Radical Biology and Medicine, 51, 257-281. doi:10.1016/j.freeradbiomed.2011.04.008

[5] Rossner Jr., P. and Sram, R.J. (2012) Immunochemical detection of oxidatively damaged DNA. Free Radical Research, 46, 492-522. doi:10.3109/10715762.2011.632415

[6] Azqueta, A., Lorenzo, Y. and Collins, A.R. (2009) In vitro comet assay for DNA repair: A warning concerning application to cultured cells. Mutagenesis, 24, 379-381. doi:10.1093/mutage/gep009
[7] Rim, K.T. and Kim, S.J. (2010) Prevention of occupational cancer with phytochemicals. Cancer Prevention Research, 15, 1-18.

[8] Liviac, D., Creus, A. and Marcos, R. (2009) Genotoxicity analysis of two halonitromethanes, a novel group of disinfection by-products (DBPs), in human cells treated in vitro. Environmental Research, 109, 232-238. doi:10.1016/i.envres.2008.12.009

[9] Chen, S.C., Chen, C.H., Tioh, Y.L., Zhong, P.Y., Lin, Y.S and Chye, S.M. (2010) Para-phenylenediamine induced DNA damage and apoptosis through oxidative stress and enhanced caspase-8 and -9 activities in Mardin-Darby canine kidney cells. Toxicology in Vitro, 24, 1197-1202. doi:10.1016/j.tiv.2010.02.011

[10] Xie, W., Wang, K., Robertson, L.W. and Ludewig, G. (2010) Investigation of mechanism(s) of DNA damage induced by 4-monochlorobiphenyl (PCB3) metabolites. Environment International, 36, 950-961. doi:10.1016/j.envint.2009.12.004

[11] Michałowicz, J. and Majsterek, I. (2010) Chlorophenols, chlorocatechols and chloroguaiacols induce DNA base oxidation in human lymphocytes (in vitro). Toxicology, 268, 171-175. doi:10.1016/j.tox.2009.12.009

[12] Landvik, N.E., Arlt, V.M., Nagy, E., Solhaug, A., Tekpli, X., Schmeiser, H.H., et al. (2010) 3-Nitrobenzanthrone and 3-aminobenzanthrone induce DNA damage and cell signalling in Hepa1c1c7 cells. Mutation Research/Fundamental and Molecular Mechanisms of Mutagenesis, 684, 11-23.

[13] Øvrevik, J., Arlt, V.M., Øya, E., Nagy, E., Mollerup, S., Phillips, D.H., et al. (2010) Differential effects of nitro-PAHs and amino-PAHs on cytokine and chemokine responses in human bronchial epithelial BEAS-2B cells. Toxicology and Applied Pharmacology, 242, 270-280. doi:10.1016/i.taap.2009.10.017

[14] Barillet, S., Jugan, M.L., Laye, M., Leconte, Y., Herlin-Boime, N., Reynaud, C., et al. (2010) In vitro evaluation of $\mathrm{SiC}$ nanoparticles impact on A549 pulmonary cells: Cyto-, genotoxicity and oxidative stress. Toxicology Letters, 198, 324-330. doi:10.1016/j.toxlet.2010.07.009

[15] Zhang, M., Lu, Y., Li, X., Chen, Q., Lu, L., Xing, M., et al. (2010) Studying the cytotoxicity and oxidative stress induced by two kinds of bentonite particles on human B lymphoblast cells in vitro. Chemico-Biological Interactions, 183, 390-396. doi:10.1016/j.cbi.2009.11.023

[16] Zhang, Y., Jiang, L., Jiang, L., Geng, C., Li, L., Shao, J., et al. (2011) Possible involvement of oxidative stress in potassium bromate-induced genotoxicity in human HepG2 cells. Chemico-Biological Interactions, 189, 186-191. doi:10.1016/j.cbi.2010.12.011

[17] Rodríguez-Mercado, J.J., Mateos-Nava, R.A. and Altamirano-Lozano, M.A. (2011) DNA damage induction in human cells exposed to vanadium oxides in vitro. Toxicology in Vitro, 25, 1996-2002. doi:10.1016/j.tiv.2011.07.009

[18] Panda, K.K., Achary, V.M., Krishnaveni, R., Padhi, B.K., Sarangi, S.N., Sahu, S.N., et al. (2011) In vitro biosynthesis and genotoxicity bioassay of silver nanoparticles using plants. Toxicology in Vitro, 25, 1097-1105. 
doi:10.1016/j.tiv.2011.03.008

[19] Asare, N., Instanes, C., Sandberg, W.J., Refsnes, M., Schwarze, P., Kruszewski, M., et al. (2012) Cytotoxic and genotoxic effects of silver nanoparticles in testicular cells. Toxicology, 291, 65-72. doi:10.1016/j.tox.2011.10.022

[20] Rim, K.T., Kim, S.J., Han, J.H., Kang, M.G., Kim, J.K. and Yang, J.S. (2011) Effects of carbon black to inflamemation and oxidative DNA damages in mouse macrophages. Molecular \& Cellular Toxicology, 7, 415-423. doi:10.1007/s13273-011-0052-7

[21] Harris, R.M, Williams, T.D., Hodges, N.J. and Waring, R.H. (2011) Reactive oxygen species and oxidative DNA damage mediate the cytotoxicity of tungsten-nickel-cobalt alloys in vitro. Toxicology and Applied Pharmacology, 250, 19-28. doi:10.1016/j.taap.2010.09.020

[22] Nemmiche, S., Chabane-Sari, D., Kadri, M. and Guiraud, P. (2011) Cadmium chloride-induced oxidative stress and DNA damage in the human Jurkat $\mathrm{T}$ cell line is not linked to intracellular trace elements depletion. Toxicology in Vitro, 25, 1191-1198. doi:10.1016/j.tiv.2010.10.018

[23] Magdolenova, Z., Bilaničová, D., Pojana, G., Fjellsbø, L.M., Hudecova, A., Hasplova, K., et al. (2012) Impact of agglomeration and different dispersions of titanium dioxide nanoparticles on the human related in vitro cytotoxicity and genotoxicity. Journal of Environmental Monitoring, 14, 455-464. doi:10.1039/c2em10746e

[24] Ursini, C.L., Cavallo, D., Fresegna, A.M., Ciervo, A., Maiello, R., Buresti, G., et al. (2012) Comparative cytogenotoxicity assessment of functionalized and pristine multiwalled carbon nanotubes on human lung epithelial cells. Toxicology in Vitro, 26, 831-840. doi:10.1016/j.tiv.2012.05.001

[25] Zhai, Q., Duan, H., Wang, Y., Huang, C., Niu, Y., Dai, Y., et al. (2012) Genetic damage induced by organic extract of coke oven emissions on human bronchial epithelial cells. Toxicology in Vitro, 26, 752-758. doi:10.1016/j.tiv.2012.04.001

[26] Knasmüller, S., DeMarini, D.M., Johnson, I. and Gerhäuser, C. (2009) Chemoprevention of cancer and DNA damage by dietary factors, Wiley-VCH. Thomson Digital, Noida, 240-241.

[27] Rim, K.T., Kim, S.J., Chung, Y.H., Kim, H.Y., Maeng, S.H. and Yu. I.J. (2007) DNA damages with Fpg/Endo III FLARE assay in cynomolgus monkeys exposed to stainless steel welding fume. Journal of Korean Society and Occupation Environmental Hygiene, 17, 272-281.

[28] Kim, S.J., Rim, K.T., Lee, S.B. and Kim. H.Y. (2008) Measurement of DNA damage with Fpg/Endo III FLARE assay and real time RT-PCR in SD rats exposed cumene. Molecular \& Cellular Toxicology, 4, 211-217.

[29] Tawfeeq, M.M., Suzuki, T., Shimamoto, K., Hayashi, H., Shibutani, M. and Mitsumori, K. (2011) Evaluation of in vivo genotoxic potential of fenofibrate in rats subjected to two-week repeated oral administration. Archives of Toxicology, 85, 1003-1011. doi:10.1007/s00204-010-0628-3

[30] Saquib, Q., Attia, S.M., Siddiqui, M.A., Aboul-Soud, M.A.M., Al-Khedhairy, A.A., Giesy, J.P., et al. (2012) Phorate-induced oxidative stress, DNA damage and tran- scriptional activation of $\mathrm{p} 53$ and caspase genes in male Wistar rats. Toxicology and Applied Pharmacology, 259, 54-65. doi:10.1016/j.taap.2011.12.006

[31] Lindeman, B., Maass, C., Duale, N., Gützkow, K.B., Brunborg, G. and Andreassen, A. (2012) Effects of perand polyfluorinated compounds on adult rat testicular cells following in vitro exposure. Reproductive Toxicology, 33, 531-537. doi:10.1016/j.reprotox.2011.04.001

[32] Gaté, L., Micillino, J.C., Sébillaud, S., Langlais, C., Cosnier, F., Nunge, H., et al. (2012) Genotoxicity of styrene-7,8-oxide and styrene in Fisher 344 rats: A 4-week inhalation study. Toxicology Letters, 211, 211-219. doi:10.1016/j.toxlet.2012.03.796

[33] Kisby, G.E., Muniz, J.F., Scherer, J., Lasarev, M.R., Koshy, M., Kow, Y.W., et al. (2009) Oxidative stress and DNA damage in agricultural workers. Journal of Agromedicine, 14, 206-214. doi:10.1080/10599240902824042

[34] Atherton, K.M, Williams, F.M., Egea González, F.J., Glass, R., Rushton, S., Blain, P.G. and Mutch, E. (2009) DNA damage in horticultural farmers: A pilot study showing an association with organophosphate pesticide exposure. Biomarkers, 14, 443-451.

doi: $10.3109 / 13547500903137265$

[35] Simoniello, M.F., Kleinsorge, E.C., Scagnetti, J.A., Mastandrea, C., Grigolato, R.A., Paonessa, A.M., et al. (2010) Biomarkers of cellular reaction to pesticide exposure in a rural population. Biomarkers, 15, 52-60. doi: $10.3109 / 13547500903276378$

[36] Liu, H.H., Lin, M.H., Liu, P.C., Chan, C.I. and Chen, H.L. (2009) Health risk assessment by measuring plasma malondialdehyde (MDA), urinary 8-hydroxydeoxyguanosine (8-OH-dG) and DNA strand breakage following metal exposure in foundry workers. Journal of Hazardous Materials, 170, 699-704. doi:10.1016/j.jhazmat.2009.05.010

[37] Liu, H.H., Lin, M.H., Chan, C.I. and Chen, H.L. (2010) Oxidative damage in foundry workers occupationally coexposed to PAHs and metals. International Journal of Hygiene and Environmental Health, 213, 93-98. doi:10.1016/j.ijheh.2009.12.005

[38] Bagryantseva, Y., Novotna, B., Rossner Jr., P., Chvatalova, I., Milcova, A., Svecova, V., et al. (2010) Oxidative damage to biological macromolecules in Prague bus drivers and garagemen: Impact of air pollution and genetic polymorphisms. Toxicology Letters, 199, 60-68. doi:10.1016/j.toxlet.2010.08.007

[39] Chen, H.L., Chen, I.J. and Chia, T.P. (2010) Occupational exposure and DNA strand breakage of workers in bottom ash recovery and fly ash treatment plants. Journal of Hazardous Materials, 174, 23-27. doi:10.1016/j.jhazmat.2009.09.010

[40] Grover, P., Rekhadevi, P.V., Danadevi, K., Vuyyuri, S.B., Mahboob, M. and Rahman, M.F. (2010) Genotoxicity evaluation in workers occupationally exposed to lead. International Journal of Hygiene and Environmental Health, 213, 99-106. doi:10.1016/j.ijheh.2010.01.005

[41] Hanova, M., Stetina, R., Vodickova, L., Vaclavikova, R., Hlavac, P., Smerhovsky, Z., et al. (2010) Modulation of DNA repair capacity and mRNA expression levels of XRCC1, hOGG1 and XPC genes in styrene-exposed 
workers. Toxicology and Applied Pharmacology, 248, 194-200. doi:10.1016/j.taap.2010.07.027

[42] Rossner Jr., P., Rossnerova, A. and Sram, R.J. (2011) Oxidative stress and chromosomal aberrations in an environmentally exposed population. Mutation Research/ Fundamental and Molecular Mechanisms of Mutagenesis, 707, 34-41.

[43] Cassini, C., Calloni, C., Bortolini, G., Garcia, S.C., Dornelles, M.A., Henriques, J.A., et al. (2011) Occupational risk assessment of oxidative stress and genotoxicity in workers exposed to paints during a working week. International Journal of Occupational and Environmental Health, 24, 308-319. doi:10.2478/s13382-011-0030-2

[44] Wang, J., Luo, X., Xu, B., Wei, J., Zhang, Z. and Zhu, H. (2011) Elevated oxidative damage in kitchen workers in Chinese restaurants. Journal of Occupational Health, 53, 327-333. doi:10.1539/joh.11-0074-OA

[45] Sellappa, S., Mani, B. and Keyan, K.S. (2011) Cytogenetic biomonitoring of road paving workers occupationally exposed to polycyclic aromatic hydrocarbons. Asian Pacific Journal of Cancer Prevention, 12(3), 713-7.

[46] Al Zabadi, H., Ferrari, L., Sari-Minodier, I., Kerautret, M.A., Tiberguent, A., Paris, C., et al. (2011) Integrated exposure assessment of sewage workers to genotoxicants: An urinary biomarker approach and oxidative stress evaluation. Environmental Health, 10, 23. doi:10.1186/1476-069X-10-23

[47] Marczynski, B., Raulf-Heimsoth, M., Spickenheuer, A., Pesch, B., Kendzia, B., Mensing, T., et al. (2011) DNA adducts and strand breaks in workers exposed to vapours and aerosols of bitumen: associations between exposure and effect. Archives of Toxicology, 1, S53-S64. doi:10.1007/s00204-011-0682-5

[48] Singh, S., Kumar, V., Thakur, S., Banerjee, B.D., Chandna, S., Rautela, R.S., et al. (2011) DNA damage and cholinesterase activity in occupational workers exposed to pesticides. Environmental Toxicology and Pharmacology, 31, 278-285. doi:10.1016/j.etap.2010.11.005

[49] Wrońska-Nofer, T., Nofer, J.R., Jajte, J., Dziubałtowska, E., Szymczak, W., Krajewski, W., et al. (2012) Oxidative DNA damage and oxidative stress in subjects occupationally exposed to nitrous oxide $\left(\mathrm{N}_{2} \mathrm{O}\right)$. Mutation Research/ Fundamental and Molecular Mechanisms of Mutagenesis, 731, 58-63.

[50] Spanou, C., Bourou, G., Dervishi, A., Aligiannis, N., Angelis, A., Komiotis, D., et al. (2008) Antioxidant and chemopreventive properties of polyphenolic compounds derived from Greek legume plant extracts. Journal of Agricultural and Food Chemistry, 56, 6967-6976. doi:10.1021/jf800842p

[51] Kim, J.K., Kim, S.J., Rim, K.T., Cho, H.W., Kim, H.Y. and Yang, J.S. (2009) Antimutagenic effects of ginsenoside $\mathrm{Rb} 1, \mathrm{Rg} 1$ in the CHO-K1 cells by benzo[a]pyrene with chromosomal aberration test and comet assay. Molecular \& Cellular Toxicology, 5, 126-132.

[52] Bouhlel, I., Bhouri, W., Limem, I., Boubaker, J., Nefatti, A., Skandrani, I., et al. (2009) Cell protection induced by Acacia salicina extracts: Inhibition of genotoxic damage and determination of its antioxidant capacity. Drug and
Chemical Toxicology, 32, 139-149. doi:10.1080/01480540802593899

[53] Cho, E.S., Jang, Y.J., Hwang, M.K., Kang, N.J., Lee, K.W. and Lee, H.J. (2009) Attenuation of oxidative neuronal cell death by coffee phenolic phytochemicals. Mutation Research, 661, 18-24. doi:10.1016/j.mrfmmm.2008.10.021

[54] Kalim, M.D., Bhattacharyya, D., Banerjee, A. and Chattopadhyay, S. (2010) Oxidative DNA damage preventive activity and antioxidant potential of plants used in Unani system of medicine. BMC Complementary and Alternative Medicine, 10, 77. doi:10.1186/1472-6882-10-77

[55] Biswas, J., Sinha, D., Mukherjee, S., Roy, S., Siddiqi, M. and Roy, M. (2010) Curcumin protects DNA damage in a chronically arsenic-exposed population of West Bengal. Human \& Experimental Toxicology, 29, 513-524. doi:10.1177/0960327109359020

[56] Alimi, H., Hfaiedh, N., Bouoni, Z., Sakly, M. and Ben, R. K. (2011) Evaluation of antioxidant and antiulcerogenic activities of Opuntia ficus indica f. inermis flowers extract in rats. Environmental Toxicology and Pharmacology, 32, 406-416. doi:10.1016/j.etap.2011.08.007

[57] Zaabat, N., Hay, A.E., Michalet, S., Darbour, N., Bayet, C., Skandrani, I., et al. (2011) Antioxidant and antigenotoxic properties of compounds isolated from Marrubium deserti de Noé. Food and Chemical Toxicology, 49, 3328-3335. doi:10.1016/j.fct.2011.08.026

[58] Cuello, S., Alberto, M.R., Zampini, I.C., Ordoñez, R.M. and Isla, M.I. (2011) Comparative study of antioxidant and anti-inflammatory activities and genotoxicity of alcoholic and aqueous extracts of four Fabiana species that grow in mountainous area of Argentina. Journal of Ethnopharmacology, 137, 512-522. doi:10.1016/j.jep.2011.06.005

[59] Grotto, D., Vicentini, J., Angeli, J.P.F., Latorraca, E.F., Monteiro, P.A.P., Barcelos, G.R.M., et al. (2011) Evaluation of protective effects of fish oil against oxidative damage in rats exposed to methylmercury. Ecotoxicology and Environmental Safety, 74, 487-493. doi:10.1016/j.ecoenv.2010.10.012

[60] Wang, T.C., Song, Y.S., Wang, H., Zhang, J., Yu, S.F., Gu, Y.E., et al. (2012) Oxidative DNA damage and global DNA hypomethylation are related to folate deficiency in chromate manufacturing workers. Journal of Hazardous Materials, 213-214, 440-446.

doi:10.1016/j.jhazmat.2012.02.024

[61] Pal, M. and Ghosh, M. (2012) Prophylactic effect of $\alpha$ linolenic acid and $\alpha$-eleostearic acid against $\mathrm{MeHg}$ induced oxidative stress, DNA damage and structural changes in RBC membrane. Food and Chemical Toxicology, 50, 2811-2818. doi:10.1016/j.fct.2012.05.038

[62] Schmelzer, C. and Döring, F. (2012) Micronutrient special issue: Coenzyme $\mathrm{Q}_{10}$ requirements for DNA damage prevention. Mutation Research/Fundamental and Molecular Mechanisms of Mutagenesis, 733, 61-68.

[63] Sram, R.J., Binkova, B. and Rossner Jr., P. (2012) Vitamin C for DNA damage prevention. Mutation Research/ Fundamental and Molecular Mechanisms of Mutagenesis, 733, 39-49. 
[64] Serpeloni, J.M., Barcelos, G.R.M., Angeli, J.P.F., Mercadante, A.Z., Bianchi, M.L.P. and Antunes, L.M.G. (2012) Dietary carotenoid lutein protects against DNA damage and alterations of the redox status induced by cisplatin in human derived HepG2 cells. Toxicology in Vitro, 26, 288-294. doi:10.1016/j.tiv.2011.11.011

[65] Gatz, S.A. and Wiesmüller, L. (2008) Take a break-Resveratrol in action on DNA. Carcinogenesis, 29, 321-332. doi:10.1093/carcin/bgm276

[66] Choi, H.Y., Chong, S.A. and Nam, M.J. (2009) Resveratrol induces apoptosis in human SK-HEP-1 hepatic cancer cells. Cancer Genomics Proteomics, 6, 263-268.

[67] Yan, Y., Yang, J.Y., Mou, Y.H., Wang, L.H., Zhou, Y.N. and $\mathrm{Wu}$, C.F. (2012) Differences in the activities of resveratrol and ascorbic acid in protection of ethanol-induced oxidative DNA damage in human peripheral lymphocytes. Food and Chemical Toxicology, 50, 168-174. doi:10.1016/j.fct.2011.10.046

[68] Liu, H., Guo, Z., Xu, L. and Hsu, S. (2008) Protective effect of green tea polyphenols on tributyltin-induced oxidative damage detected by in vivo and in vitro models. Environmental Toxicology, 23, 77-83. doi:10.1002/tox.20312

[69] Gradecka-Meesters, D., Palus, J., Prochazka, G., Segerbäck, D., Dziubałtowska, E., Kotova, N., et al. (2011) Assessment of the protective effects of selected dietary anticarcinogens against DNA damage and cytogenetic effects induced by benzo[a]pyrene in C57BL/6J mice. Food and Chemical Toxicology, 49, 1674-1683. doi:10.1016/i.fct.2011.02.021

[70] Tan, X., Zhao, C., Pan, J., Shi, Y., Liu, G., Zhou, B. et al. (2009) In vivo non-enzymatic repair of DNA oxidative damage by polyphenols. Cell Biology International, 33, 690-696. doi:10.1016/i.cellbi.2009.03.005

[71] Das, S., Rao, B.N. and Rao, B.S.S. (2011) Mangiferin attenuates methylmercury induced cytotoxicity against IMR-32, human neuroblastoma cells by the inhibition of oxidative stress and free radical scavenging potential. Chemico Biological Interactions, 193, 129-140. doi:10.1016/i.cbi.2011.06.002

[72] Wang, D., Luo, X., Zhong, Y., Yang, W., Xu, M., Liu, Y., et al. (2012) Pu-erh black tea extract supplementation attenuates the oxidative DNA damage and oxidative stress in Sprague-Dawley rats with renal dysfunction induced by subchronic 3-methyl-2-quinoxalin benzenevinylketo1,4-dioxide exposure. Food and Chemical Toxicology, 50, 147-154. doi:10.1016/j.fct.2011.10.069

[73] Halliwell, B. (2000) Why and how should we measure oxidative DNA damage in nutritional studies? How far have we come? The American Journal of Clinical Nutrition, 72, 1082-1087.

[74] Au, W.W., Giri, A.K. and Ruchirawat, M. (2010) Challenge assay: A functional biomarker for exposure-induced DNA repair deficiency and for risk of cancer. Interna- tional Journal of Hygiene and Environmental Health, 213, 32-39. doi:10.1016/j.ijheh.2009.09.002

[75] Fracasso, M.E., Doria, D., Bartolucci, G.B., Carrieri, M., Lovreglio, P., Ballini, A., et al. (2010) Low air levels of benzene: Correlation between biomarkers of exposure and genotoxic effects. Toxicology Letters, 192, 22-28. doi:10.1016/j.toxlet.2009.04.028

[76] Ginsberg, G., Angle, K., Guyton, K. and Sonawane, B. (2011) Polymorphism in the DNA repair enzyme XRCC1: Utility of current database and implications for human health risk assessment. Mutation Research/Reviews in Mutation Research, 727, 1-15. doi:10.1016/j.mrrev.2011.02.001

[77] Ruchko, M.V., Gorodnya, O.M., Zuleta, A., Pastukh, V.M. and Gillespie, M.N. (2011) The DNA glycosylase Ogg1 defends against oxidant-induced mtDNA damage and apoptosis in pulmonary artery endothelial cells. Free Radical Biology and Medicine, 50, 1107-1113. doi:10.1016/j.freeradbiomed.2010.10.692

[78] Singh, S., Kumar, V., Vashisht, K., Singh, P., Banerjee, B.D., Rautela, R.S., et al. (2011) Role of genetic polymorphisms of $C Y P 1 A 1, C Y P 3 A 5, C Y P 2 C 9, C Y P 2 D 6$, and $P O N 1$ in the modulation of DNA damage in workers occupationally exposed to organophosphate pesticides. Toxicology and Applied Pharmacology, 257, 84-92. doi:10.1016/j.taap.2011.08.021

[79] Jensen, A., Løhr, M., Eriksen, L., Grønbæk, M., Dorry, E., Loft, S., et al. (2012) Influence of the OGG1 Ser326Cys polymorphism on oxidatively damaged DNA and repair activity. Free Radical Biology and Medicine, 52, 118-125. doi:10.1016/j.freeradbiomed.2011.09.038

[80] Simonelli, V., Mazzei, F., D’Errico, M. and Dogliotti, E. (2012) Gene susceptibility to oxidative damage: From single nucleotide polymorphisms to function. Mutation Research/Fundamental and Molecular Mechanisms of Mutagenesis, 731, 1-13.

[81] Markkanen, E., Hübscher, U. and van Loon, B. (2012) Regulation of oxidative DNA damage repair: the adenine: 8-oxo-guanine problem. Cell Cycle, 11, 1070-1075. doi:10.4161/cc.11.6.19448

[82] Loft, S., Danielsen, P., Løhr, M., Jantzen, K., Hemmingsen, J.G., Roursgaard, M., et al. (2012) Urinary excretion of 8-oxo-7,8-dihydroguanine as biomarker of oxidative damage to DNA. Archives of Biochemistry and Biophysics, 518, 142-150. doi:10.1016/j.abb.2011.12.026

[83] Dusinska, M., Staruchova, M., Horska, A., Smolkova, B., Collins, A., Bonassi, S. and Volkovova, K. (2012) Are glutathione $\mathrm{S}$ transferases involved in DNA damage signalling? Interactions with DNA damage and repair revealed from molecular epidemiology studies. Mutation Research/Fundamental and Molecular Mechanisms of $\mathrm{Mu}$ tagenesis, in press. 